\title{
Generation and characterization of monoclonal antibodies specific to Coenzyme $A$
}

\author{
O. M. Malanchuk ${ }^{1}$, G. G. Panasyuk ${ }^{1}$, N. M. Serbin ${ }^{1}$, I. T. Gout ${ }^{2}$, V. V. Filonenko ${ }^{1}$ \\ ${ }^{1}$ Institute of Molecular Biology and Genetics, NAS of Ukraine \\ 150, Akademika Zabolotnoho Str., Kyiv, Ukraine, 03680 \\ ${ }^{2}$ Institute of Structural and Molecular Biology, University College London, \\ Gower Street, London, WC1E 6BT, UK \\ filonenko@imbg.org.ua
}

\begin{abstract}
Aim. Generation of monoclonal antibodies specific to Coenzyme A. Methods. Hybridoma technique. KLH carrier protein conjugated with CoA was used for immunization. Screening of positive clones was performed with BSA conjugated to CoA. Results. Monoclonal antibody that specifically recognizes CoA and CoA derivatives, but not its precursors ATP and cysteine has been generated. Conclusion. In this study, we describe for the first time the production and characterization of monoclonal antibodies against CoA. The monoclonal antibody $1 \mathrm{~F} 10$ was shown to recognize specifically CoA in Western blotting, ELISA and immunoprecipitation. These properties make this antiboby a particularly valuable reagent for elucidating CoA function in health and disease.
\end{abstract}

Ke y w o r ds: CoA, hybridoma technique, monoclonal antibody.

\section{Introduction}

Coenzyme $\mathrm{A}(\mathrm{CoA})$ is an essential cofactor in all living organisms. CoA and its thioester derivatives (acetyl-CoA, malonyl-CoA, HMG-CoA etc) participate in the diverse anabolic and catabolic pathways. Apart from participating in cellular metabolism as substrates and intermediates, CoA and its derivatives, such as acetyl-CoA, can also directly regulate the activity of proteins by allosteric mechanisms and gene expression by protein acetylation [1].

The levels of CoA and its derivatives in mammalian cells and tissues as well as in different cellular compartments are tightly regulated by a diverse range of stimuli and stresses, including nutrients, hormones, cellular metabolites, fasting and refeeding. It has been demonstrated that the total level of CoA is reduced in response to insulin, glucose, fatty acids and pyruvate, whereas glucagon and glucocorticoids have an opposite effect $[2,3]$. The changes in the le- vel of CoA occur at several pathological conditions, such as diabetes, cancer and cardiac hypertrophy [412]. Defective CoA biosynthesis is implicated in neurodegeneration with brain iron accumulation (NBIA) [13-15]. However, the exact role of CoA and its derivatives in the pathogenesis of the above disorders is not well understood. The reliable and accurate assays for measuring CoA species in biological samples are essential for better understanding of the roles of CoA and CoA derivatives under physiological and pathological conditions.

At present, there are a number of methods for measuring $\mathrm{CoA}$ and its derivatives based on enzymatic assays, HPLC and mass spectrometry quantifications [16]. However, each of these approaches has its own limitations. Therefore, development of novel tools and approaches for measuring CoA species in different subcellular compartments or different cell types and tissues would be highly useful for studying the consequences of altered CoA levels on cellular processes.

(C) 2015 O. M. Malanchuk et al.; Published by the Institute of Molecular Biology and Genetics, NAS of Ukraine on behalf of Biopolymers and Cell. This is an Open Access article distributed under the terms of the Creative Commons Attribution License (http://creativecommons.org/licenses/by/4.0/), which permits unrestricted reuse, distribution, and reproduction in any medium, provided the original work is properly cited 
The aim of this work was to generate monoclonal antibodies specific to CoA which could be used in research and for the development of highly sensitive ELISA-based assays aimed at detecting CoA and its derivatives in biological samples.

\section{Materials and Methods}

Generation of antigens for mice immunization, screening of hybridoma clones and antibodies characterisation. For mice immunization and selection of positive clones, CoA was directly conjugated to maleimide-activated keyhole limpet hemocyanin (KLH) and bovine serum albumin (BSA) correspondingly. In brief, $1 \mathrm{mg}$ of maleimide-activated KLH or BSA (Pierce) was dissolved in $500 \mathrm{ul} \mathrm{H}_{2} \mathrm{O}$ and then mixed with $500 \mu \mathrm{l}$ of $\mathrm{CoA}\left(0,5 \mathrm{mg} / \mathrm{ml}\right.$ in $\left.\mathrm{H}_{2} \mathrm{O}\right)$. The mix was incubated on the wheel at room temperature for $2 \mathrm{hrs}$ before extensive dialysis in PBS. After testing the efficiency of conjugation, prepared samples of KLH-CoA and BSA-CoA were aliquoted and stored at $-20^{\circ} \mathrm{C}$.

To test the specificity of anti-CoA antibodies in WB and immunoprecipitation assays CoA was reversibly cross-linked to BSA with the use of N-succinimidyl 3-(2-pyridyldithio) propionate (SPDP, Pierce) according to the manufacturer's recommendations. For this, BSA (3 mg) in $100 \mathrm{ul} \mathrm{PBS}$ was mixed with SPDP (0.36 mg) dissolved in $10 \mu \mathrm{l}$ of DMSO and incubated at $37^{\circ} \mathrm{C}$ for $1 \mathrm{~h}$. Activated BSA was desalted on G25 column to remove unreacted SPDP and incubated for $2 \mathrm{~h}$ at $37^{\circ} \mathrm{C}$ with $0.2 \mathrm{mg} \mathrm{CoA}$ in a total volume of $110 \mu \mathrm{l}$. Unreacted CoA was removed by desalting on G25 column and BSA-S-CoA was aliqouted and stored at $-20^{\circ} \mathrm{C}$.

Production of hybridomas. Female BALB/c mice (6-8 weeks old) were immunized with $20 \mu \mathrm{g}$ of KLH-CoA in complete Freund's adjuvant by intraperitoneal injections (i.p.) every two weeks. When the titer of anti-CoA antibody in the sera of immunized mice reached $10^{-4}$, the production of hybridomas was performed according to a standard protocol [17]. In brief, immunized mice were boosted with 20 $\mu \mathrm{g}$ of antigen in PBS by i.p. injection. Three days later, spleenocytes from immunized mice and SP2/0 myeloma cells cultured in RPMI 1640 medium containing $20 \%$ fetal calf serum (FCS) were fused in the presence of PEG (MW2000, Merck, Germany). Primary screening of hybridoma culture media was performed 7 days later using ELISA. Isolated positive clones were subcloned by limiting dilution method [17].

ELISA assay. Ninety-six-well polystyrene plates were incubated with $0.3 \mu \mathrm{g} /$ well of BSA-CoA for 2

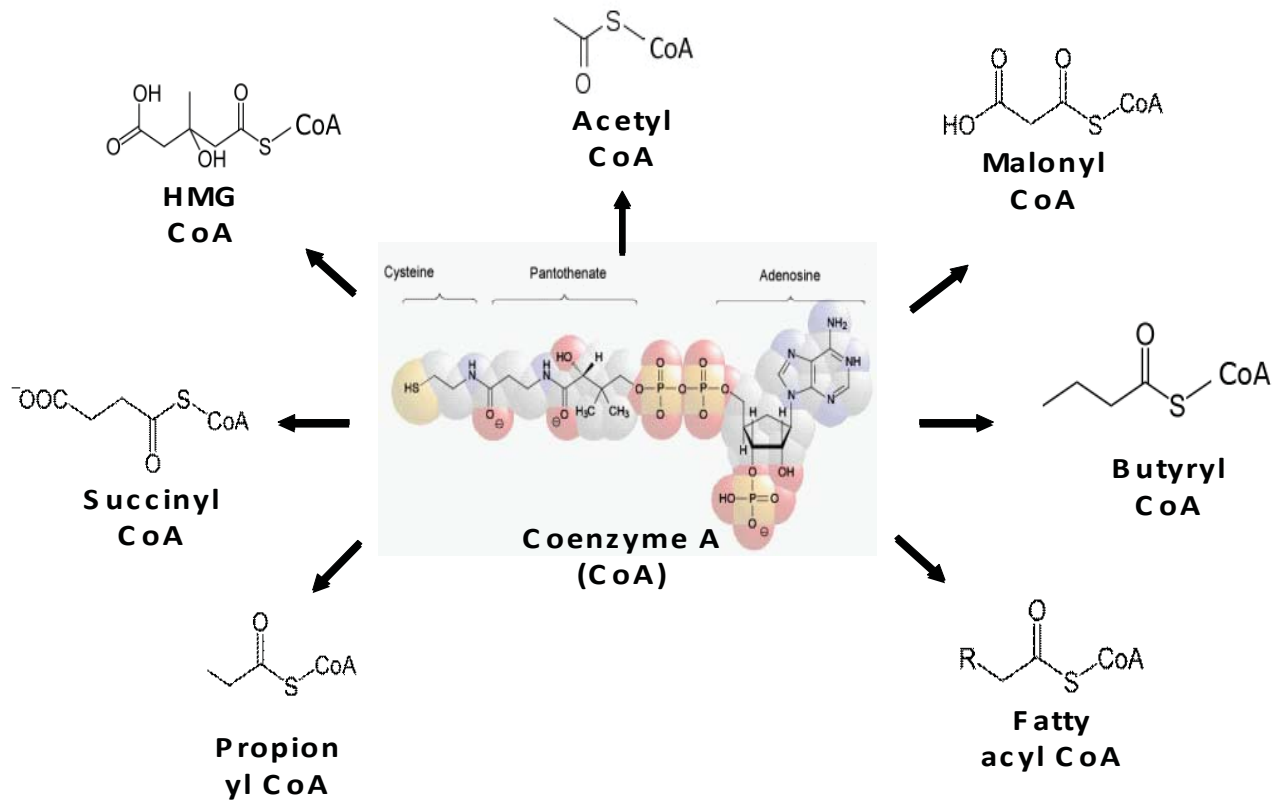

Fig. 1. Schematic structure of $\mathrm{CoA}$ and its thioester derivatives 


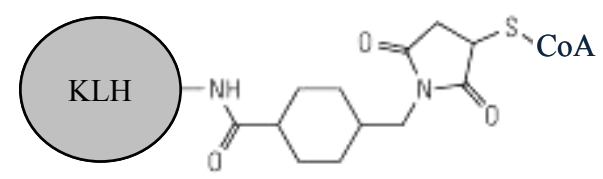

KLH-CoA

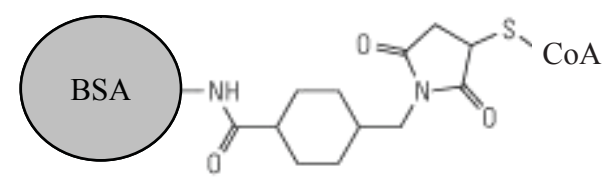

BSA-CoA

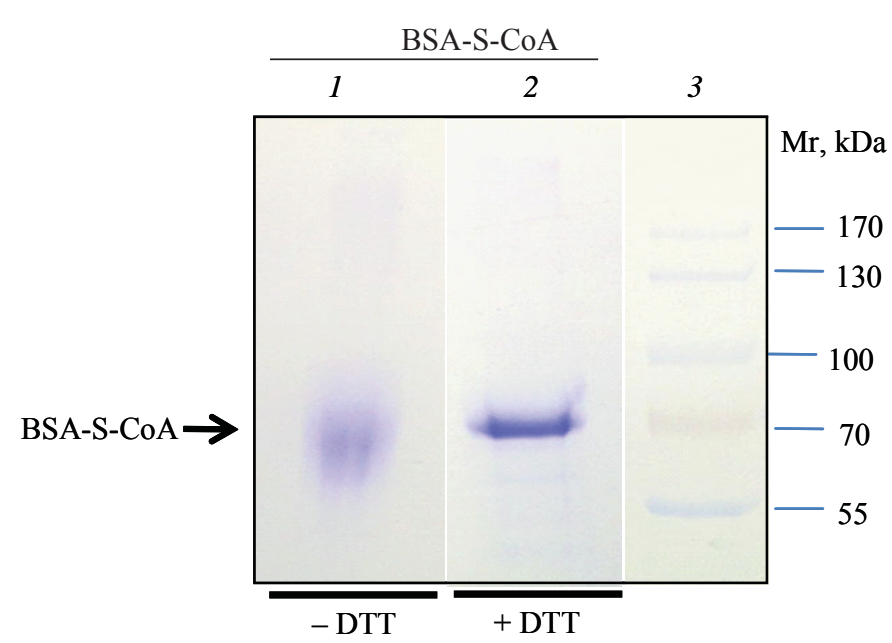

$B$

Fig. 2. (A) Schematic structures of KLH-CoA and BSA-CoA conjugates used for immunization and hybridoma screening respectively. (B) Gel electrophoresis of BSA cross-linked with CoA by SPDP. BSA-S-CoA (2 $\mu \mathrm{g})$ untreated (1) and treated (2) with DTT. 3 protein standards. SDS-PAGE (10\%)

$\mathrm{h}$ at $37^{\circ} \mathrm{C}$. The plates were then washed three times with PBS containing $0.1 \%$ Tween-20 (PBS-T) (Sigma, USA) and incubated with $200 \mu$ of $2 \%$ bovine serum albumin (BSA) in PBS (pH 7.4) for $1 \mathrm{~h}$ at room temperature in order to block non-specific binding of antibodies. Subsequently, the plates were loaded with $100 \mu 1$ aliquots of hybridoma media and were incubated for $1 \mathrm{~h}$ at $37^{\circ} \mathrm{C}$ followed by three washes with PBS-T. After washing, $100 \mu$ l of horseradish peroxidase (HRP)-conjugated goat anti-mouse IgG antibodies (1:5000 v/v, Promega, USA) were added to each well and incubated at $37{ }^{\circ} \mathrm{C}$ for $1 \mathrm{~h}$. Plates were washed again three times, before $100 \mu \mathrm{l}$ of substrate solution $\left(0.02 \% \mathrm{H}_{2} \mathrm{O}_{2}, 0.5 \mathrm{mg} / \mathrm{ml} \mathrm{2.2'-}\right.$ azino-bis(3-ethylbenzothiazoline-6-sulfonic acid) sodium salt (Sigma, USA), 0.1 M citrate-phosphate buffer ( $\mathrm{pH}$ 5.8)) was added to each well. After 15min incubation at $37^{\circ} \mathrm{C}$, the absorbance of the each well was determined at $490 \mathrm{~nm}$.

Competitive ELISA. This analysis was performed according to the above protocol with minor modifications. The assay was carried out in 96 well plates, containing immobilized BSA-CoA $(0.3 \mu \mathrm{g} /$ well $)$. The primary mAb $1 \mathrm{~F} 10(10 \mu \mathrm{g}$ in $100 \mathrm{ul}$ PBS $)$ was then added together with different concentrations $(5 \times$ $\times 10^{-1} \mathrm{mM}, 5 \times 10^{-2} \mathrm{mM}, 5 \times 10^{-3} \mathrm{mM}, 5 \times 10^{-4} \mathrm{mM}$, $5 \times 10^{-5} \mathrm{mM}, 5 \times 10^{-6} \mathrm{mM}$ ) of CoA, ATP, cysteine, succinyl-CoA, malonyl-CoA or glutaryl-CoA. The mixture was incubated for $1 \mathrm{hr}$ at room temperature and the assay developed as described above.

Western blot analysis. BSA-S-CoA (100 ng per well) was heat treated in sample buffer with and without DTT, resolved by SDS/PAGE and electrotransferred onto Immobilon-P membrane (Millipore, USA). The membrane was divided into strips and blocked with $0.5 \%$ BSA in PBS for $1 \mathrm{~h}$ at room temperature followed by a single wash with PBS containing $0.1 \%$ Tween 20. Strips were incubated with hybridoma media from selected clones for $2 \mathrm{~h}$ at room temperature. After three washes, a peroxidase-conjugated antimouse secondary antibody (Promega, USA) was added to the strips and incubated for $1 \mathrm{~h}$ at room temperature. Strips were washed three times, and developed by ECL detection system (Amersham, Sweden).

Immunoprecipitation. Culture media $(500 \mu \mathrm{l})$ from selected positive hybridoma clones 1F10/B11, 9F10/ B6 and 9F6/G1 were incubated with $25 \mu 1$ of $50 \%$ suspension of Protein A Sepharose CL-4B (Amersham, 


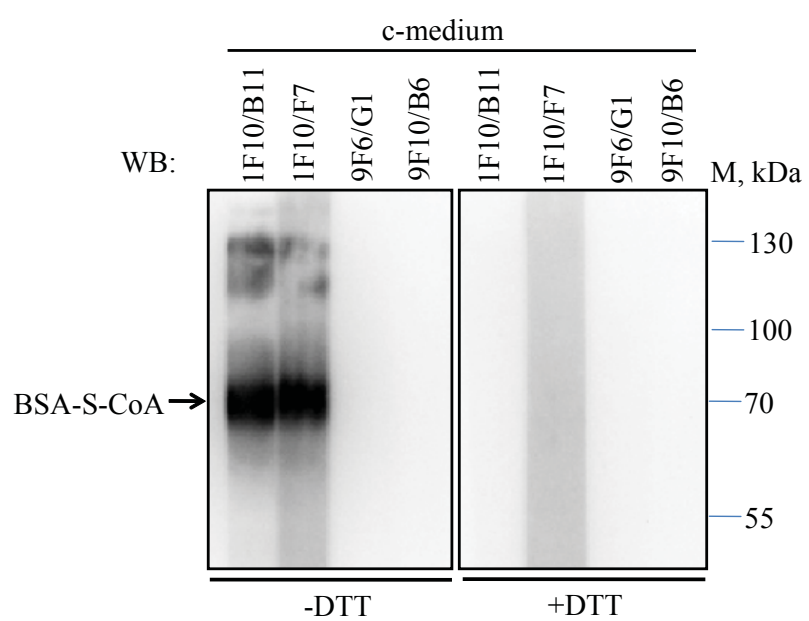

Fig. 3. Testing the specificity of anti-CoA mAbs. WB analysis of BSA-S-CoA (100ng) by anti-CoA mAbs of hybridoma clones 1F10, 9F6 and 9F10. BSA-S-CoA samples before electroforetical separation were treated in sample buffer with or without DTT

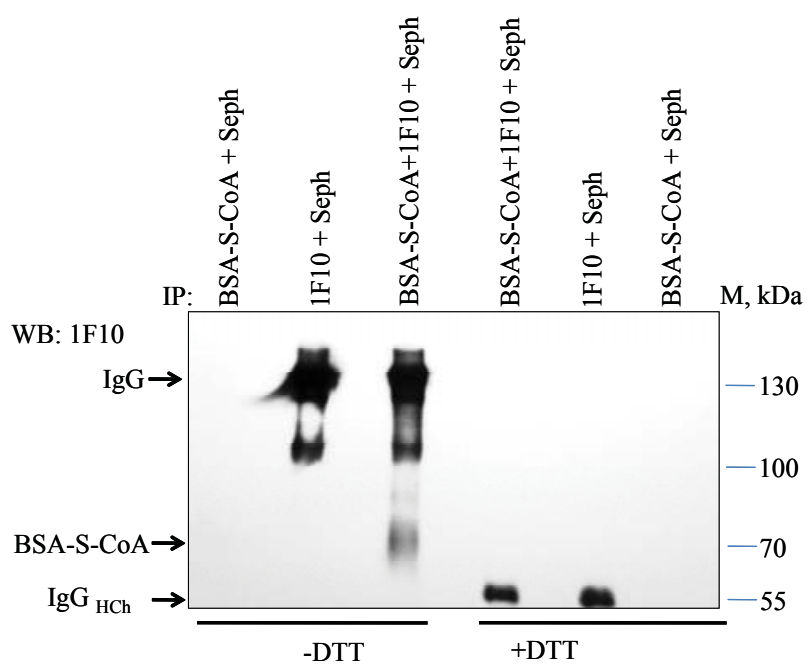

Fig. 4. Testing of selected anti-CoA mAbs in immunoprecipitation assay. WB analysis of BSA-S-CoA immunoprecipitated by 1 F10 mAbs. Immune complexes before electroforetical separation were treated in sample buffer with or without DTT

Sweden) on the wheel for $2 \mathrm{~h}$ at $4{ }^{\circ} \mathrm{C}$. Then beads were washed twice with PBS and incubated with $0,5 \mu \mathrm{g}$ BSA-S-CoA in PBS $(500 \mu \mathrm{l})$ for $2 \mathrm{~h}$ at $4{ }^{\circ} \mathrm{C}$. After incubation, beads were washed three times with $1 \mathrm{ml}$ PBS containing $0,1 \%$ Triton X-100. Immune complexes were removed from beads by boiling in Laemmli sample buffer (with or without DTT), separated by SDSPAGE and immunoblotted with mAbs 1F10/B11.
Purification of MAbs from ascitic fluid. BALB/c mice were injected with $0.5 \mathrm{ml}$ of Pristane and 7-10 days later inoculated with $5 \cdot 10^{6}$ of hybridoma cells. The ascitic fluid was collected after 7-10 days. The fraction of immunoglobulins was precipitated from ascitic fluid with $50 \%$ ammonium sulfate and used for affinity purification by Protein A Sepharose CL4B (Amersham, Sweden) chromatography. The IgG fractions were pulled together and dialyzed in a PBS. The aliquots of purified antibodies were stored at $-70{ }^{\circ} \mathrm{C}$ with $50 \%$ glycerol.

\section{Results and Discussion}

Coenzyme A was discovered by Lipmann in 1945 as a heat-stable cofactor required for many enzyme-catalysed acetylation reactions. He later determined the structure for CoA and was awarded the Nobel Prize in 1953 for this achievement. CoA has a unique structure which allows it to function as a master acyl group carrier and carbonyl-activating group, resulting in a diverse range of metabolically active thioester derivatives, including acetyl-CoA, malonyl-CoA, 3-hydroxy-3-methylglutaryl-CoA etc (Fig. 1). In spite of a vast interest in elucidating the regulation and function of CoA and its derivatives under physiological and pathological conditions, there are no commercially available polyclonal or monoclonal antibodies specific to CoA.

The main focus of this study was to generate monoclonal antibodies against CoA, which could be used in various immunological assays, including Western blotting, immunoprecipitation, and ELISA to allow a more detailed study of the physiological and pathophysiological role of $\mathrm{CoA}$ in health and disease. In order to obtain monoclonal anti-CoA antibodies, we prepared CoA conjugated to maleimide-activated KLH and BSA (Fig. 2). Immunization of animals was performed according to the standard protocol using KLH-CoA as an antigen. The titer of anti-CoA antibodies in immunized mice was monitored using BSA-CoA. When the titer of anti-CoA antibody in the sera of immunized mice reached $10^{-4}$, spleen cells were fused with the Sp2/0 myeloma cells using the PEG method according to [17]. Screening of positive anti-CoA hybridoma clones was performed against BSA-CoA conjugate. Following two rounds 
of ELISA screening, only three positive hybridoma clones were selected and designated as 9F6, 9F10 and 1F10. To confirm the specificity of selected hybridoma clones against CoA, we analyzed their specificity towards CoA reversibly crosslinked to BSA (Fig. 2B) by SPDP. SPDP is a short-chain crosslinker for amine-tosulfhydryl conjugation via NHS-ester and pyridyldithiol reactive groups that form cleavable (reducible) disulfide bonds with cysteine sulfhydryls. As shown in Fig. 3, only subclones of 1F10 hybridoma showed specific recognition of CoA conjugated with BSA. When BSA-S-CoA was treated with DTT, 1F10 mAbs could not recognize the antigen demonstrating the specificity towards CoA (Fig. 3). Then, we tested the ability of selected hybrid clones to immunoprecipitate BSA-SCoA conjugate. This analysis revealed that only $1 \mathrm{~F} 10$ $\mathrm{mAb}$ specifically precipitated BSA conjugated with CoA (Fig. 4). However, the immunoprecipitation of BSA-S-CoA was not very efficient, indicating low affinity of 1 F10 mAb towards CoA. No specific immunoprecipitation of BSA-S-CoA under various experimental conditions was observed with hybridoma clones 9F6 and 9F10 (data not shown).

The biosynthesis of CoA involves five enzymatic steps that are highly conserved from prokaryotes to eukaryotes and requires pantothenic acid, cysteine and ATP. (Fig. 5). Hypothetically, the 1F10 epitope may correspond to various regions of CoA structure. We have attempted to locate the epitope for $1 \mathrm{~F} 10 \mathrm{mAb}$ by performing competitive ELISA (Fig. 5) and demonstrated that ATP and cysteine did not compete with CoA for the interaction with anti-CoA mAb (1F10). At the same time, CoA and its derivatives succinyl-CoA, malonyl-CoA and glutaryl-CoA efficiently deprived the recognition of BSA-CoA by 1 F10 mAb. Further studies showed that the 1F10 epitope doesn't correspond to the panthothenate moiety of CoA (data not shown). Taking this into account, data suggest that the antigenic determinant for $1 \mathrm{~F} 10 \mathrm{mAbs}$ may cover the junctions between ATP and pantothenate or pantothenate and cysteine. We can't exclude that the 1F10 epitope covers all three blocks of CoA. Further studies are required to map the 1F10 epitope with more precision.

In conclusion, this study describes the production and characterisation of first monoclonal anti-
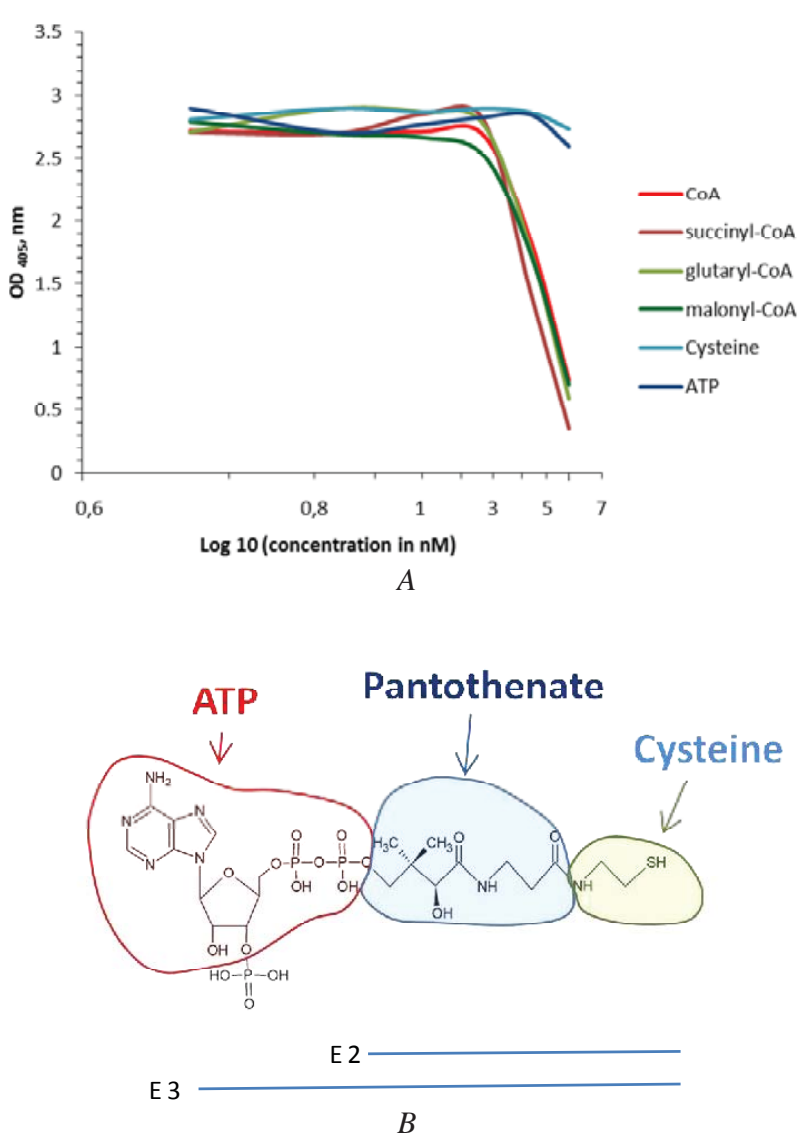

Fig. 5. (A) Deprivation of anti-CoA specificity of mAb (1F10) by ATP, cysteine, CoA derivatives and CoA. Semi-logarithmic plot of competitive ELISA data. The concentration of CoA and CoA derivatives in samples is scaled logarithmically $(\log 10)$ for the $\mathrm{X}$-axis. Y-axis - absorbance at $405 \mathrm{~nm}$. (B) Schematic structure of CoA and potential localization of the 1F10 epitope

body that specifically recognises CoA and its derivatives. We anticipate that generated anti-CoA 1 F10 antibody could be used for academic research and the development of reliable and highly sensitive ELISA-based immunoassays, allowing the detection of CoA and its derivatives in biological samples.

\section{REFERENCES}

1. Shi $L, T u B P$. Protein acetylation as a means to regulate protein function in tune with metabolic state. Biochem Soc Trans. 2014;42(4):1037-42.

2. Smith CM, Cano ML, Potyraj J. The relationship between metabolic state and total CoA content of rat liver and heart. J Nutr. 1978;108(5):854-62. 
3. Smith CM, Savage CR Jr. Regulation of coenzyme A biosynthesis by glucagon and glucocorticoid in adult rat liver parenchymal cells. Biochem J. 1980;188(1):175-84.

4. Leonardi R, Zhang YM, Rock CO, Jackowski S. Coenzyme A: back in action. Prog Lipid Res. 2005;44(2-3):125-53.

5. Perry RJ, Camporez JP, Kursawe R, Titchenell PM, Zhang D, Perry CJ, Jurczak MJ, Abudukadier A, Han MS, Zhang XM, Ruan HB, Yang X, Caprio S, Kaech SM, Sul HS, Birnbaum MJ, Davis RJ, Cline GW, Petersen KF, Shulman GI. Hepatic acetyl CoA links adipose tissue inflammation to hepatic insulin resistance and type 2 diabetes. Cell. 2015;160(4):745-58.

6. Kamphorst JJ, Chung MK, Fan J, Rabinowitz JD. Quantitative analysis of acetyl-CoA production in hypoxic cancer cells reveals substantial contribution from acetate. Cancer Metab. 2014;2:23.

7. Schug ZT, Peck B, Jones DT, Zhang Q, Grosskurth S, Alam IS, Goodwin LM, Smethurst E, Mason S, Blyth K, McGarry L, James D, Shanks E, Kalna G, Saunders RE, Jiang M, Howell $M$, Lassailly F, Thin MZ, Spencer-Dene B, Stamp G, van den Broek NJ, Mackay G, Bulusu V, Kamphorst JJ, Tardito S, Strachan D, Harris AL, Aboagye EO, Critchlow SE, Wakelam MJ, Schulze A, Gottlieb E. Acetyl-CoA synthetase 2 promotes acetate utilization and maintains cancer cell growth under metabolic stress. Cancer Cell. 2015;27(1):57-71.

8. Huang J, Xu L, Huang Q, Luo J, Liu P, Chen S, Yuan X, Lu Y, Wang $P$, Zhou $S$. Changes in short-chain acyl-coA dehydrogenase during rat cardiac development and stress. J Cell Mol Med. 2015;19(7):1672-88.

9. Kolwicz SC Jr, Olson DP, Marney LC, Garcia-Menendez L, Synovec RE, Tian R. Cardiac-specific deletion of acetyl CoA carboxylase 2 prevents metabolic remodeling during pressure-overload hypertrophy. Circ Res. 2012;111(6):728-38.

10. Abo Alrob O, Lopaschuk GD. Role of CoA and acetyl-CoA in regulating cardiac fatty acid and glucose oxidation. Biochem Soc Trans. 2014;42(4):1043-51.

11. Naquet P, Pitari G, Duprè S, Galland F. Role of the Vnn1 pantetheinase in tissue tolerance to stress. Biochem Soc Trans. 2014;42(4):1094-100.

12. Jackowski S, Leonardi R. Deregulated coenzyme A, loss of metabolic flexibility and diabetes. Biochem Soc Trans. 2014; 42(4):1118-22.

13. Colombelli C, Aoun M, Tiranti V. Defective lipid metabolism in neurodegeneration with brain iron accumulation (NBIA) syndromes: not only a matter of iron. J Inherit Metab Dis. 2015;38(1):123-36.

14. Hayflick SJ. Defective pantothenate metabolism and neurodegeneration. Biochem Soc Trans. 2014;42(4):1063-8.

15. Venco $P$, Dusi $S$, Valletta L, Tiranti V. Alteration of the coenzyme A biosynthetic pathway in neurodegeneration with brain iron accumulation syndromes. Biochem Soc Trans. 2014;42(4):1069-74.
16. Tsuchiya Y, Pham U, Gout I. Methods for measuring CoA and $\mathrm{CoA}$ derivatives in biological samples. Biochem Soc Trans. 2014;42(4):1107-11.

17. Harlow E, Lane D. Antibodies: a laboratory manual. Cold Spring Harbor Lab Press, 1998. 726 p.

\section{Отримання та характеристика} моноклональних антитіл, специфічних до КоА

О. М. Маланчук, Г. Г. Панасюк, Н. М. Сербин, І. Т. Гут, В. В. Філоненко

Мета. Отримати та охарактеризувати моноклональні антитіла, специфічні до КоА. Методи. Гібридомна технологія. Для імунізації було використано КоА, кон'югований з білкомносієм KLH. Скринінг позитивних клонів проводили з використанням БСА, кон'югованого з КоА. Результати. Отримано моноклональні антитіла, що специфічно розпізнають КоА та КоА-похідні та не розпізнають його попередників АТФ та цистеїну. Висновки. Вперше описано створення та характеристику моноклональних антитіл проти КоА. Моноклональні антитіла 1F10 специфічно розпізнають КоА в Вестерн блотингу, ІФА та імунопреципітації. Такі властивості антитіл вказують на перспективність використання для аналізу функцій КоА в нормі та за патологій.

Кл юч о в і с л о в а: КоА, гібридомна технологія, моноклональні антитіла.

\section{Получение и характеристика моноклональных антител, специфичных к КоА}

О. Н. Маланчук, А. Г. Панасюк, Н. Н. Сербин, И. Т. Гут, В. В. Филоненко

Цель. Получить и охарактеризовать моноклональные антитела, специфичные к КоА. Методы. Гибридомная технология. Для иммунизации был использован КоА, конъюгированный с белком-носителем KLH. Скрининг положительных клонов проводили с использованием БСА, конъюгиванного с КоА. Результаты. Получено моноклональные антитела, которые специфично распознают КоА и КоА-производные и не распознают его предшественников - АТФ и цистеина. Выводы. Впервые описано получение моноклональных антител к КоА. Показано, что моноклональные антитела 1F10 специфически распознают КоА в вестерн плоте, ИФА и иммунопреципитации. Такие свойства антител указывают на возможность их использования для анализа функций КоА в норме и при патологиях.

Кл юч е в ы е с л о в а: КоА, гибридомная технология, моноклональные антитела.

Received 28.03.2015 